\title{
Standardization of Gujarati sweets recipes and assessment of their nutritive values
}

\author{
Gita Rathod and Nilambri R. Dave
}

Received: 02.10.2020; Revised: 01.11.2020; Accepted: 21.11.2020

See end of the paper for authors' affiliations

\section{Gita Rathod}

S.B. Gardi Institute of Home

Science, Saurashtra University,

Rajkot (Gujarat) India

Email : dr.geetarthod@gmail.com
ABSTRACT : In ancient times man was consuming row foods. With the search of fire he started cooking foods. As the time passed with the evolution of modern technology various kinds of processed foods are now available. In general, Gujarati food pattern is almost a balanced food. Presently, nutritive values of foods are generally derived from food tables, which are based on raw foods. It has been established that there is a definite loss of nutritive values especially vitamins and minerals due to cooking procedures. This study contained of a survey work of various food preparations daily consumed by various families residing in Saurashtra. This will highlight the food pattern of this region. A standard recipe was derived for all food preparations of people of Saurashtra region based on the results of the survey, which then was prepared in laboratory and analysed for different nutrient contents. Recipes which were commonly included in Gujrati sweets. It can be revealed from Table 1 that, Shira contains good amount of moisture compare to other cereal products of sweets. Protein was found to be considerably high in Gol papdi compare to Laddu because in Gol papdi Jaggery was used and in Laddu there was used a powder sugar. Fat content of Laddu and Gol papdi is very much high and contains low fat. Carbohydrates content of comparatively high because there is low fat content. Because of the high fat content of Laddu and Gol papdi these products were found to be high in energy level compare to other products. Carotene level was also found high in Laddu and comparative to Gol papdi and Shira because there was use of both (oil and Ghee) in Laddu and Gol papdi because there was use of Jaggery and was lowest in Semolina Shira because semolina contents low Iron compare to wheat. Ash was found to be highest in Gol papdi and lowest in Semolina Shira.

KEY WORDS: Gujarati sweets, Nutritive values, Gol papdi, Laddu

- HOW TO CITE THIS PAPER : Rathod, Gita and Dave, Nilambri R. (2020). Standardization of Gujarati sweets recipes and assessment of their nutritive values. Asian J. Home Sci., 15 (2) : 309-313, DOI: 10.15740/HAS/AJHS/15.2/309-313. Copyright@ 2020: Hind Agri-Horticultural Society. 